\title{
Microbiology Susceptibility Previous Occurrence
}

National Cancer Institute

\section{Source}

National Cancer Institute. Microbiology Susceptibility Previous Occurrence. NCI

Thesaurus. Code C162324.

An indication or description that a particular microbiology susceptibility event happened in the past. 